\title{
Novel Carcinoembryonic-Antigen-(CEA)-Specific Pretargeting System to Assess Tumor Cell Viability after Irradiation of Colorectal Cancer Cells
}

\author{
Birgit Meller ${ }^{1,5}$, Margarete Rave-Fränck², Christian Breunig 3 , Markus Schirmer ${ }^{4}$, Manfred Baehre5, \\ Roger Nadrowitz ${ }^{6}$, Torsten Liersch7, Johannes Meller ${ }^{1}$
}

\begin{abstract}
Purpose: To date, no valid imaging modality exists for early response prediction to neoadjuvant radiochemotherapy in carcinoembryonic-antigen-(CEA)-expressing rectal cancers (UICC stages II and III). It is hypothesized that the uptake of an anti-CEA antibody is directly related to the number of viable tumor cells and may be quantified by immuno-positron emission tomography (immuno-PET). Therefore, we evaluated a novel pretargeting system using TF2, a humanized bispecific trivalent monoclonal antibody (mAb), directed against CEA and the IMP-288-peptide, a hapten for binding radiometals for imaging. Uptake and kinetics of the pretargeting system were investigated in vitro prior to and after irradiation.

Methods: TF2 was labeled with ${ }^{131} \mathrm{I}$ and IMP-288 with ${ }^{111} \mathrm{InCl}_{3}$. The colorectal cancer cell lines HT29, SW480, and T84 with known varying CEA expression were incubated ( $\leq 72$ hours) with ${ }^{131}$ I-TF2 or the TF2-111In-IMP-288 pretargeting system. Parallel cultures were irradiated with 2-10 Gy high-energy photons. Tracer uptake, proliferation, apoptosis, and CEA-RNA expression of cancer cells were investigated.

Results: The uptake of tracers was dependent on CEA expression and cell count of the cell lines (uptake/10 cells: $0.3 \%$ in HT29, $1.5 \%$ in SW480, and $14 \%$ in T84, $p<0.001$ ). The TF2- ${ }^{111}$ In-IMP-288 pretargeting system showed a higher uptake after 4 and 72 hours compared to ${ }^{131} \mathrm{I}$-TF2 in parallel cultures. Only in one cell line (SW480) an increased apoptosis after irradiation could be detected. Irradiation increased dose dependently both the specific uptake of ${ }^{131}$ I-TF2 and of the TF2- ${ }^{111}$ In-IMP-288 system (4-fold in HT29 and T84 after 10 Gy (72 hours), p < 0.001). These results were CEA-mRNA independent.

Conclusions: This novel pretargeting system allows the quantitative analysis of CEA-expressing colorectal cancer cells and represents a promising tool for evaluation of tumor cell viability after irradiation.
\end{abstract}

Key words: Bispecific antibody · Colorectal cancer · Carcinoembryonic antigen · Irradiation · Pretargeting

Strahlenther Onkol 2011;187:120-6

DOI $10.1007 /$ s00066-010-2191-5

\section{Neues Carcinoembryonales-Antigen-(CEA-)spezifisches Pretargeting-System zur Bestimmung der Tumorzellviabilität nach Bestrahlung kolorektaler Karzinomzellen}

Hintergrund: Derzeit gibt es beim CEA-exprimierenden Rektumkarzinom (der UICC-Stadien II und III) keine valide Diagnostik zur frühzeitigen Response-Beurteilung auf eine neoadjuvante Radiochemotherapie. Allerdings wird vermutet, daß mit einer Immuno-Positronen-Emissions-Tomographie (Immuno-PET) und einem anti-CEA-Antikörper die Anzahl viabler Tumorzellen nach erfolgter Radiatio quantifizierbar ist. Demzufolge wurde von unserer Arbeitsgruppe zur Etablierung eines Immuno-PETs ein neues Pretargeting-System evaluiert. Dieses Pretargeting-System besteht aus dem humanisierten bispezifischen trivalenten monoklonalen Antikörper (TF2), der an CEA sowie an das radioaktiv markierte Hapten-Peptid IMP-288 bindet. Wir untersuchten in vitro die Bindung und Kinetik dieses Pretargeting-Systems vor und nach Radiatio.

\footnotetext{
${ }^{1}$ Department of Nuclear Medicine, University Medical Center, Georg-August-University Göttingen, Göttingen Germany,

${ }^{2}$ Department of Radiotherapy and Radiation Oncology, University Medical Center, Georg-August-University Göttingen, Göttingen Germany,

${ }^{3}$ Department of Radiology and Nuclear Medicine, University of Lübeck, Lübeck, Germany,

${ }^{4}$ Department of Clinical Pharmacology, University Medical Center, Georg-August-University Göttingen, Göttingen, Germany,

${ }^{5}$ Department of Nuclear Medicine, Martin-Luther-University Halle, Halle, Germany,

${ }^{6}$ Department of Radiotherapy, University of Lübeck, Lübeck, Germany,

${ }^{7}$ Department of General Surgery, University Medical Center, Georg-August-University Göttingen, Göttingen, Germany.
}

Received: June 28, 2010; accepted: November 11, 2010

Published Online: January 24, 2011 


\begin{abstract}
Methoden: TF2 wurde mit ${ }^{131} \mathrm{I}$ und IMP-288 mit ${ }^{111} \mathrm{InCl}_{3}$ markiert. Die Inkubation $(\leq 72 \mathrm{~h})$ der kolorektalen Tumorzelllinien HT29, SW480 und T84 mit unterschiedlicher CEA-Expression erfolgte mit ${ }^{131}$ I-TF2 und dem TF2- ${ }^{111} \mathrm{In}$-IMP-288-Pretargeting-System. Parallelkulturen wurden mit 2-10 Gy hochenergetischer Photonen bestrahlt. Neben der Bindung der markierten Substanzen wurden die Proliferation, Apoptose und CEA-RNA-Expression der Tumorzellen untersucht.

Ergebnisse: Der Tracer-Uptake korrelierte sowohl mit der CEA-Expression als auch der Zellzahl der jeweiligen Zelllinie (Uptake/10 Zellen: $0,3 \%$ in HT29, 1,5\% in SW480 und $14 \%$ in T84; p < 0,001). Das Pretargeting-System wurde nach $4 \mathrm{~h}$ und $72 \mathrm{~h}$ stärker gebunden als ${ }^{131}$ I-TF2 in Parallelkulturen. Lediglich in einer Zelllinie (SW480) konnte eine erhöhte Apoptoserate nach Bestrahlung nachgewiesen werden. Die Radiatio erhöhte dosisabhängig die spezifische Aufnahme des Pretargeting-Systems (4fach in HT29 und T84 nach 10 Gy (72 h), p < 0,001). Diese Ergebnisse waren CEA-mRNA-unabhängig.

Schlussfolgerungen: Das neue Pretargeting-System erlaubt eine quantitative Analyse der CEA-Expression kolorektaler Tumorzellen und ist eine vielversprechende Methode zur Evaluation der Tumorzellviabilität nach Radiatio.
\end{abstract}

Schlüsselwörter: Bispezifischer Antikörper · Kolorektale Karzinome · Carcinoembryonales Antigen · Radiatio · Pretargeting

\section{Introduction}

Based on several trials of the German Rectal Cancer Study Group, preoperative 5-fluorouracil (5-FU)-based radiochemotherapy (RCT) is recommended for treatment of UICC stage II and III rectal cancer in Germany [32-34, 38, 42, 43]. However, individual tumor response to RCT is heterogeneous, ranging from complete regression to total resistance [35]. From the clinical point of view, early detection of individual tumor response is mandatory for risk-adapted multimodal treatment in future trials [22].

Usually response to neoadjuvant RCT is evaluated by contrast-enhanced computed tomography (CT), magnetic resonance imaging (MRI), and endorectal ultrasound $[4,11,16,18$, $23,36]$. These methods are not able to distinguish tumor from necrotic and/or fibrotic tissue. Furthermore, the extent of RCTinduced cancer death combined with shrinkage of the initial tumor infiltration depth can not be determined [1]. Other imaging methods like ${ }^{18} \mathrm{FDG}$ ( $\left[{ }^{18} \mathrm{~F}\right]$ fluoro-2-deoxy-D-glucose) positron emission tomography (FDG-PET/CT) seem to be useful in management of colorectal cancer [3, 28, 29]. But in neoadjuvantly treated rectal cancer patients, the nonspecific glucose uptake caused by the tumor microenvironment itself or by RCTinduced tumor cell damage followed by inflammatory processes are serious limitations for the use of FDG-PET/CT in response prediction $[10,14]$. In this dilemma, immuno-PET offers an innovative imaging approach using direct targeting of biomarkers (e.g., carcinoembryonic antigen [CEA]; CEACAM5 as surrogate markers for tumor cell viability) before, during, and after multimodal treatment $[9,17,19,20,27,41,45]$.

CEA is expressed on the tumor cell surface of more than $90 \%$ of colorectal cancers and has been a useful marker for cancer detection in molecular imaging for nearly 35 years [13]. The tumor-to-background ratio (T/BG-R) of directly radiolabeled anti-CEA monoclonal antibodies $(\mathrm{mAb})$ is poor and most crucial for scintigraphic detection of cancer. In order to improve the T/BG-R, several CEA-directed pretargeting systems using bispecific $\mathrm{mAb}$ and a radiolabeled hapten-peptide have been described [8.19, 40]. In these systems, the nonlabeled $\mathrm{mAb}$ is separated from the radioisotope, thereby, allowing time for the $\mathrm{mAb}$ to localize its target and clear from the blood. The isotope is attached to a small compound with rapid renal clearance from blood and tissues.

TF2, a novel humanized, recombinant bs-mAb, assembles two Fab fragments from a humanized anti-CEACAM5 mAb (hMN-14, labetuzumab) and a Fab fragment of an anti-HSG (histamine-succinyl-glycine) antibody into a unique tri-Fab structure [37]. This bs-mAb has been paired with the haptenpeptide IMP-288 that contains two copies of the hapten histamine-succinyl-glycine (HSG) to enhance local retention [24]. This peptide has been radiolabeled with several radiometals for imaging and therapy. In preclinical models $\mathrm{T} / \mathrm{BG}-\mathrm{R}$ of more than 40-fold compared to directly labeled IgG molecules have been described $[15,37]$.

Within the interdisciplinary research unit KFO179 (subject: "Biological basis of individual tumor response in patients with rectal cancer"), sponsored by the German Research Foundation, we are preparing to use a TF2 pretargeting system with ${ }^{68} \mathrm{Ga}$-labeled IMP-288 for immuno-PET/CT imaging in patients with UICC stage II/III rectal cancer before, during, and after preoperative RCT. In this clinical study, the efficacy of immuno-PET/CT imaging for response prediction to RCT will be determined. As a first step of this challenge using a novel pretargeting system, we hypothesize that CEA expression is a quantitative biomarker for early detection of viable tumor cells. Thus, in vitro studies using the colorectal cancer cell lines HT29, SW480, and T84 with known varying CEA expression were performed to assess the following:

- What are the kinetics of TF2 and IMP-288 binding to colorectal cancer cell lines?

- Is the uptake of the bs-mAb and IMP-288 related to CEA expression?

- Does irradiation influence bs-mAb uptake?

- Are changes in uptake associated with apoptosis or with changes in CEA-RNA expression?

\section{Materials and Methods \\ Radiolabeling of TF2 and IMP-288}

Radiolabeling of $0.5 \mathrm{mg}$ TF2 (10 mg/ml PBS, IBC Pharmaceuticals, Inc., Morris Plains, NJ, USA) with $50 \mathrm{MBq}$ sodium 
iodide was performed as previously described [30]. The radiometallation of $5 \mu \mathrm{g}$ of IMP-288 (DOTA-D-Tyr-D-Lys(HSG)D-Glu-D-Lys(HSG)- $\mathrm{NH}_{2}$ ), provided by Immunomedics, Inc. (Morris Plains, NJ, USA) with $37 \mathrm{MBq}{ }^{111} \mathrm{InCl}_{3}$ (Tyco Healthcare, NL) was performed in $1 \mathrm{ml}$ of $0.5 \mathrm{M}$ acetate buffer ( $\mathrm{pH}$ 5). Reaction mixture was heated for 20 minutes at

Table 1. Primers: Carcinoembryonic antigen (CEA) and reference genes glyceraldehyde-3-phosphate dehydrogenase (GAPDH), hypoxanthine phosphoribosyltransferase 1 (HPRT1), ubiquitin $\mathrm{C}(U B C)$.

Tabelle 1. Primer: Carcinoembrionales Antigen (CEA) und Referenzgene Glycerinaldehyd-3phosphat-Dehydrogenase (GAPDH), Hypoxanthin-Phosphoribosyl-Transferase 1 (HPRT1), Ubiquitin $C(U B C)$.

\begin{tabular}{llll}
\hline Gene & Forward primer $\left(5^{\prime} \rightarrow 3^{\prime}\right)$ & Reverse primer $\left(5^{\prime} \rightarrow 3^{\prime}\right)$ & Source \\
\hline CEA & CCCAGACTCGTCTTACCTTTCG & TTGGCGATAAAGAGAACTTGTGT & a \\
GAPDH & CCCTTCATTGACCTCAACTACAT & ACGATACCAAAGTTGTCATGGAT & {$[2]$} \\
HPRT1 & TGACACTGGCAAAACAATGCA & GGTCCTTTTCACCAGCAAGCT & {$[2]$} \\
UBC & CGGTGAACGCCGATGATTAT & ATCTGCATTGTCAAGTGACGA & {$[5]$} \\
\hline
\end{tabular}

The indicated primer sequences were taken from the following sources: a PrimerBank http://pga.mgh.harvard. edu/primerbank/index.html), [2], [5].

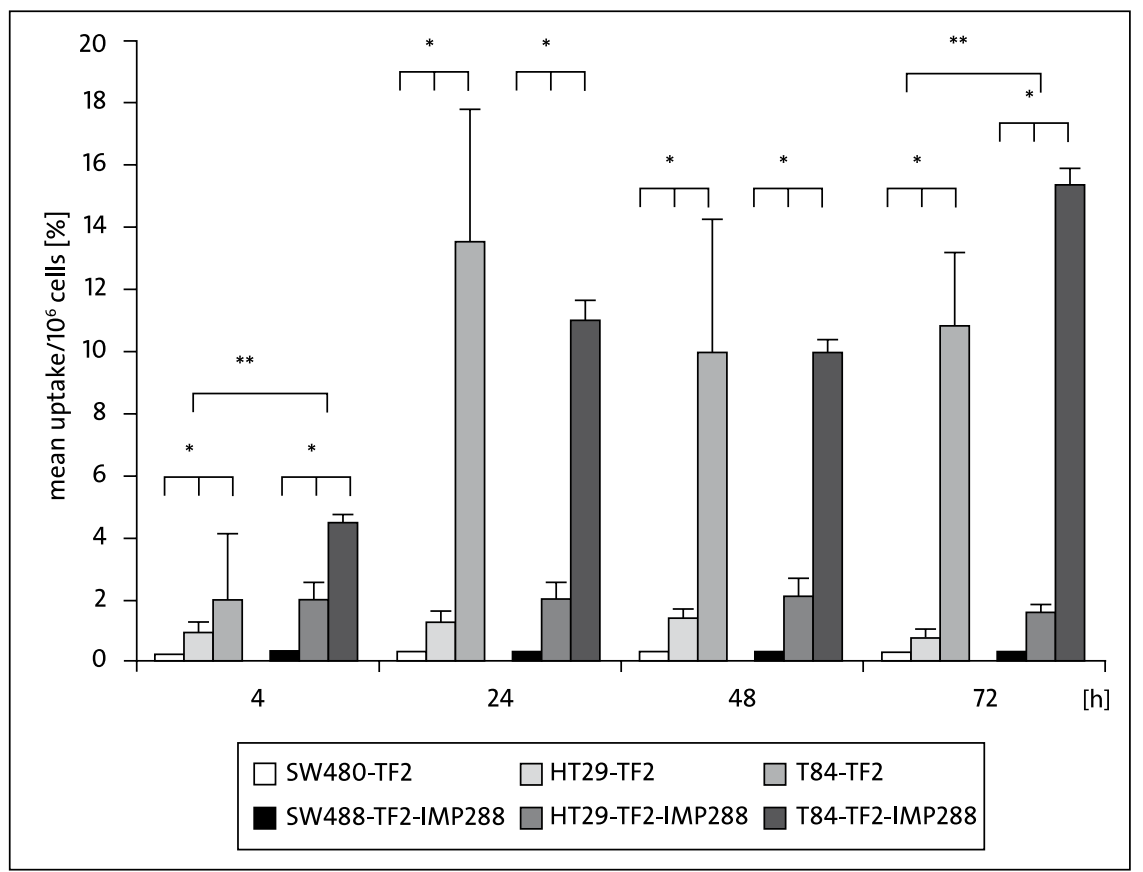

Figure 1. Mean uptake $/ 10^{6}$ cells of ${ }^{1{ }^{1}} \mathrm{I}-\mathrm{TF}_{2}\left(\mathrm{TF}_{2}\right)$ and the $\mathrm{TF}_{2}{ }^{{ }^{11}}{ }^{11} \mathrm{I}$-IMP-288 pretargeting system (TF2-IMP288). The individual uptake of ${ }^{131} \mid-T_{2}$ and TF2- ${ }^{11} I n-I M P-288$ depended significantly on the individual CEA expression (in SW 480 : $0.7 \mathrm{ng}$ CEA $/ 10^{6}$ cells $/ 10$ days, in HT29: $25 \mathrm{ng}$ CEA $/ 10^{6}$ cells $/ 10$ days, in T84 $600 \mathrm{ng}$ CEA $/ 10^{6}$ cells $/ 10$ days, $\left[n=9\right.$ each, $\left.\left.{ }^{*} p<0.001\right]\right)$. After 4 hours and after 72 hours, the uptake of the pretargeted "'In-IMP-288 was significantly higher than the uptake of the directly labeled antibody ${ }^{131} \mid-T_{2}\left({ }^{* *} \mathrm{p}<0.05\right)$. Error bars $=$ standard deviation (SD).

Abbildung 1. Mittlerer Uptake/106 Zellen von ${ }^{131} \mathrm{I}-\mathrm{TF}_{2}$ (TF2) und des ${ }^{1}{ }^{1} \mid \mathrm{n}$-IMP-288-TF2-Pretargeting-Systems (TF2-IMP288). Die Bindung von ${ }^{131}-\mathrm{TF}_{2}$ und TF2- ${ }^{11} \mathrm{In}-\mathrm{IMP}-288$ war signifikant von der jeweiligen CEA-Expression abhängig (bei SW480: 0,7 ng CEA/10 ${ }^{6}$ Zellen/10 d; bei HT29: $25 \mathrm{ng}$ CEA $/ 10^{6}$ Zellen/10 d; bei T84 600 ng CEA $/ 10^{6}$ Zellen/10 d; [jeweils $n=9,{ }^{*} p<0.001$ ]). Nach $4 \mathrm{~h}$ und nach $72 \mathrm{~h}$ war die Aufnahme TF2-"'1'In-IMP-288-Pretargeting-Systems signifikant höher als die des direkt markierten Antikörpers $\left.{ }^{131} \mid-T_{2}{ }^{* *} p<0,05\right)$. Fehlerbalken = Standardabweichung (SD). $\mathrm{ml}$ cell culture medium according to their recommendations. The cell line SW480 is known to produce $0.7 \mathrm{ng} \mathrm{CEA} / \mathrm{ml} / 10^{6}$ cells in 10 days, T84 to produce $600 \mathrm{ng}$ $\mathrm{CEA} / \mathrm{ml} / 10^{6}$ cells in 10 days (ATCC), and HT29 was reported to produce $2.5 \mathrm{ng} \mathrm{CEA} / \mathrm{ml} / 10^{6}$ cells in 24 hours [6].

\section{Uptake Measurements and Cell Count}

To assess the capacity of cells for the labeled compounds, $1 \mu \mathrm{g} / \mathrm{ml}$ medium of ${ }^{131} \mathrm{I}-\mathrm{TF} 2$ or $20 \mathrm{ng} / \mathrm{ml}$ medium ${ }^{111} \mathrm{In}$ IMP-288 was simultaneously applied to three parallel cell cultures for each interval $(4,24,48$, and 72 hours, respectively) to achieve a final activity of ${ }^{131} \mathrm{I}-\mathrm{TF} 2$ at $\mathrm{t}_{0}=100 \mathrm{kBq} / \mathrm{ml}$ medium or ${ }^{111} \mathrm{In}-\mathrm{IMP}-288$ at $\mathrm{t}_{0}=70 \mathrm{kBq} / \mathrm{ml}$ medium. Before measuring tracer uptake, culture medium was discarded, and the cells were washed twice with phosphate buffered saline (PBS) buffer $\mathrm{pH} 7.4$ [30].

\section{Irradiation and Apoptosis}

Apoptosis was determined by a Caspase-Glo ${ }^{\mathrm{TM}}$ 3/7 Assay Systems (Progema) in an ElisaReader (GENIOS PLUS, Tecan Deutschland $\mathrm{GmbH}$, Crailsheim, Germany). Cell cultures were irradiated 24 hours and 48 hours before measurement with single fractions of 2 Gy and 4 Gy. Sham irradiated cultures were incubated with 200 $\mu \mathrm{l}$ PBS, $100 \mathrm{kBq} / \mathrm{ml}^{131} \mathrm{I}-\mathrm{TF} 2$ or $1 \mu \mathrm{g} / \mathrm{ml}$ TF2 and $70 \mathrm{kBq} / \mathrm{ml}^{111} \mathrm{In}-\mathrm{IMP}-288$. Two hours before measurement, cells were released by actase/EDTA and equal cell counts were seeded into a 96-well plate. The luminescence referenced against untreated cells was determined at 30 minutes, 2 hours, 4 hours, and 24 hours after assay start $(n=6)$.

\section{RNA Analysis}

Total RNA of $10^{6}$ cells per sample (T84 and SW480, 0-10 Gy) was iso- 
lated (RNeasy mini kit, Qiagen, Hilden, Germany). The amount of RNA was quantified spectrophotometrically. Reverse transcription to complementary DNA was effected

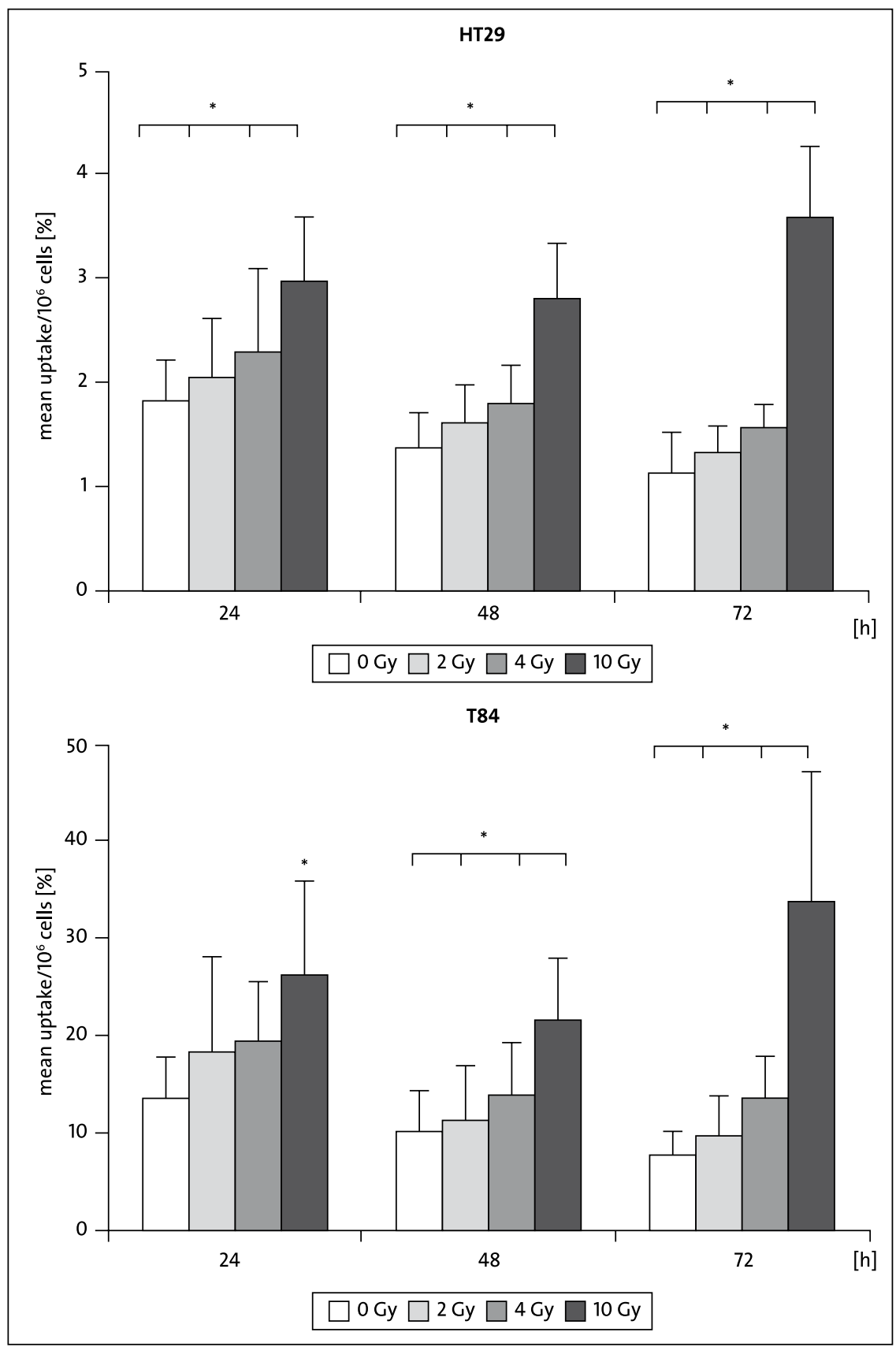

Figure 2. Mean uptake $/ 10^{6}$ cells of HT29 and T84 cells irradiated with o-10 Gy high energy photons. The uptake of ${ }^{131} \mid-T_{2}$ increased significantly after irradiation $(n=9, p<0.05)$. The increase was significantly dose dependent in both cell lines 48 hours and 72 hours after irradiation $\left(\mathrm{n}=9,{ }^{*} \mathrm{p}<0.05\right)$. Error bars $=$ standard deviation (SD).

Abbildung 2. Mittlerer Uptake $/ 10^{6}$ Zellen von HT29- und T84-Zellen, die mit o-10 Gy hochenergetischer Photonen bestrahlt wurden. Die Bindung von ${ }^{131}$-TF2 stieg nach Bestrahlung signifikant an $(n=9, p<0.05) .48 \mathrm{~h}$ und $72 \mathrm{~h}$ nach Bestrahlung war diese Zunahme in beiden Zelllinien signifikant dosisabhängig $\left(n=9,{ }^{*} p<0,05\right)$. Fehlerbalken = Standardabweichung. for 1 hour with $1 \mu \mathrm{g}$ total RNA using SuperScript II reverse transcriptase (Invitrogen, Carlsbad, CA, USA) and 20 units per sample recombinant RNase inhibitor (USB, Cleveland, $\mathrm{OH}, \mathrm{USA})$. Transcript numbers of target and reference genes were quantified relatively by real-time PCR using HotStart-IT SYBR Green qPCRMaster Mix (USB, Cleveland, $\mathrm{OH}$, USA) in a real-time PCR machine (HT7900, Applied Biosystems, Foster City, CA, USA). PCR conditions were 45 cycles with annealing at $60^{\circ} \mathrm{C}$ for 20 $\mathrm{s}$ and elongation at $72{ }^{\circ} \mathrm{C}$ for $40 \mathrm{~s}$ for each primer pair. Specific primer pairs were synthesized by MWG-Biotech AG (Ebersberg, Germany). Efficacy of primers was tested by serial dilution (factor 625) and specificity by melting curve and agarose gel electrophoresis. Data of CEA were normalized to weighted mean expression of GAPDH, HPRT1, and UBC serving as reference genes. Primer sequences are given in Table 1.

\section{Statistical Analysis}

Statistical analyses (Statistical Analysis Software: SPSS 15.0 for Windows) were performed using nonparametric tests (Wilcoxon, Mann-Whitney). Medians (M), means (m), and standard deviations (SD) were calculated. Differences were considered significant at $\mathrm{p}<0.05$. Figures display the means and standard deviations as well as the statistical results of particular experiments.

\section{Specific Tracer Uptake and Influence on Proliferation}

Cell cultures received either $1 \mu \mathrm{g} /$ $\mathrm{ml}{ }^{131} \mathrm{I}-\mathrm{TF} 2(100 \mathrm{kBq} / \mathrm{ml})$ or $1 \mu \mathrm{g} / \mathrm{ml}$ ${ }^{131} \mathrm{I}-\mathrm{TF} 2$ and $50 \mu \mathrm{g} / \mathrm{ml}$ cold antibody. Specific uptake was expressed as the percent uptake by subtracting ${ }^{131} \mathrm{I}-\mathrm{TF} 2$ uptake in the presence of excess cold TF2. Antibody uptake was determined through 72 hours ( $n=9$ intervals each). To determine the influence of ${ }^{131} \mathrm{I}-\mathrm{TF} 2$ and TF2 on proliferation, control cultures were supplemented either with $200 \mu \mathrm{l}$ phosphate buffered saline (PBS) or with excess $(50 \mu \mathrm{g} / \mathrm{ml})$ cold antibody.

Cell cultures received $20 \mathrm{ng} / \mathrm{ml}$ ${ }^{111} \mathrm{In}-\mathrm{IMP}-288(70 \mathrm{kBq} / \mathrm{ml})$ or $20 \mathrm{ng} / \mathrm{ml}$ 
${ }^{111}$ In-IMP-288 and $200 \mathrm{ng} / \mathrm{ml}$ cold IMP-288. Parallel cultures were preincubated for 24 hours with $1 \mu \mathrm{g} / \mathrm{ml}$ cold TF2 prior to ${ }^{111}$ In-IMP-288 application ( $\mathrm{n}=9$ each interval). To determine the influence of IMP-288 on proliferation, the medium of control cultures was supplemented with $200 \mu \mathrm{l}$ PBS or with $20 \mathrm{ng} / \mathrm{ml}$ cold IMP-288. Uptake experiments after irradiation were performed as previously described [30].

\section{Results}

Radiolabeling yield was $>90 \%$. The radiochemical purity of ${ }^{131} \mathrm{I}-\mathrm{TF} 2$ decreased slowly from $97.8(\mathrm{~m}) \pm 1.2 \%$ shortly after labeling to $93.6 \% \pm 1.8 \%$ after 72 hours. The radiochemical purity of ${ }^{111}$ In-IMP-288 decreased from $95.2 \% \pm 0.2 \%$ shortly after labeling to $92.1 \% \pm 1.2 \%$ after 72 hours, independent of temperature and solvent.

Table 2. Percentage of CEA expression of T84 cells standardized to the expression sham-irradiated controls at the given times. CEA expression levels were also normalized to the expression of housekeeping genes (GAPDH, HPRT1, and UBC).

Tabelle 2. Prozentsatz der CEA-Expression von T84-Zellen bezogen auf die Expression scheinbestrahlter Kontrollen zu demselben Zeitpunkt. Die Werte der CEA-Expression wurden zusätzlich auf die Expression der Housekeeping-Gene (GAPDH, HPRT1, UBC) bezogen.

\begin{tabular}{rlcc}
\hline & 24 hours & 48 hours & 72 hours \\
\hline 2 Gy & 68 & 75 & 100 \\
4 Gy & 95 & 112 & 96 \\
10 Gy & 70 & 140 & 172 \\
\hline
\end{tabular}

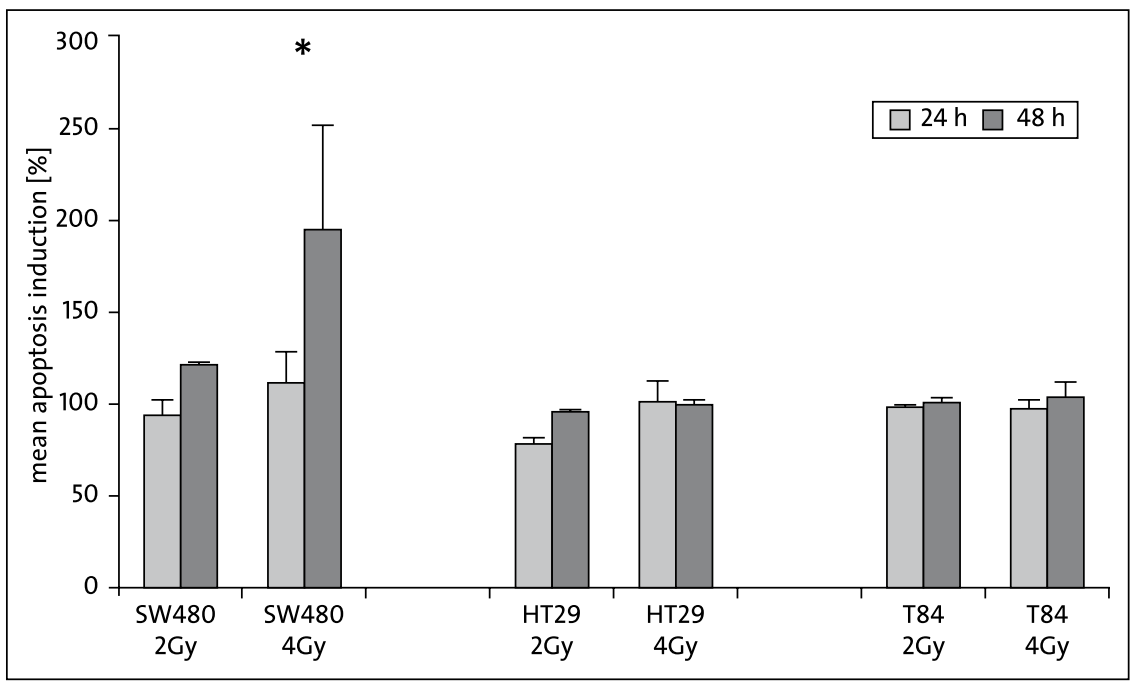

Figure 3. Mean apoptosis levels of irradiated cells standardized to those of sham-irradiated cells 24 hours and 48 hours after irradiation. Significantly increased apoptosis was detected in SW 480 cells 48 hours after irradiation with 4 Gy $\left(n=6,{ }^{*} p<0.05\right)$. Error bars $=$ standard deviation (SD).

Abbildung 3. Mittlere Apoptoserate von bestrahlen Zellkulturen im Verhältnis zu der scheinbestrahler Zellen 24 and $48 \mathrm{~h}$ nach Bestrahlung. Eine signifikante Zunahme der Apoptose wurde bei SW 480 -Zellen $48 \mathrm{~h}$ nach Bestrahlung mit 4 Gy nachgewiesen $\left(n=6,{ }^{*} p<0,05\right)$. Fehlerbalken $=$ Standardabweichung.

\section{${ }^{131} \mathrm{I}-\mathrm{TF} 2$ and ${ }^{11}$ In-IMP-288 Uptake}

At each time, the uptake of ${ }^{131} \mathrm{I}-\mathrm{TF} 2$ was specific and significant $(\mathrm{p}<0.01)$ in T84 and HT29 cells. The uptake maximum of ${ }^{131} \mathrm{I}-\mathrm{TF} 2$ in $\mathrm{T} 84$ cells $(14 \pm 4.3 \%)$ was observed after 24 hours or after 48 hours in HT29 cells $(1.5 \% \pm 0.39 \%)$. After 72 hours the uptake of ${ }^{131} \mathrm{I}-\mathrm{TF} 2$ decreased significantly $(\mathrm{p}<0.05)$ in both cell lines. Uptake of ${ }^{131} \mathrm{I}-\mathrm{TF} 2$ was appreciably lower in SW480 cells, with an average specific uptake maximum of $0.3 \%(\mathrm{p}<0.05)$.

At all times uptake of the ${ }^{111}$ In-labeled peptide without preincubation with TF 2 was $<0.1 \%$ in all cell lines. Incubation with 10-fold excess of cold IMP-288 had no influence on the binding of ${ }^{111}$ In-IMP-288.

The kinetics of the ${ }^{131}$ I-TF2 and TF2-111 In-IMP-288, respectively, pretargeting systems are shown in Figure 1. Specific binding for pretargeted ${ }^{111}$ In-IMP-288 was found in all cell lines at all time points $(\mathrm{p}<0.05)$. Specific binding of ${ }^{111}$ In-IMP-288 was detected in the first interval examined (4 hours) and was significantly higher at this interval than that measured with ${ }^{131} \mathrm{I}-\mathrm{TF} 2(\mathrm{p}<0.05)$. Uptake of the pretargeted ${ }^{111}$ In-IMP-288 measured at 4 hours remained relatively fixed over 72 hours in the SW480 and HT29 cells, while it increased in the T84 cells at 24 hours, but thereafter, uptake of the ${ }^{131} \mathrm{I}-$ TF2 and TF2-111 In-IMP-288 remained at a more elevated level (14\%). ${ }^{131}$ I-TF2 and TF2- ${ }^{111}$ In-IMP-288 uptake varied significantly based on CEA expression (Figure 1). The correlation between individual cell count and TF2- ${ }^{111}$ In-IMP-288 uptake was almost linear in all three cell lines (not shown). RNA analyses confirmed the reported ratio of CEA expression between T84 and SW480. CEA expression in T84 cells reached the level of housekeeping genes (CEA in T84: 23-24 cycles, CEA in SW480: 34 cycles). Cell proliferation and viability was not affected by unlabeled or radiolabeled TF2 or IMP-288.

\section{Irradiation}

Compared to sham-irradiated cells the specific uptake of TF2- ${ }^{111}$ In-IMP-288 in SW480 cells increased slightly after irradiation. This up to 1.5 -fold enhancement was significant at 48 and 72 hours after irradiation with 10 Gy $(\mathrm{p}<0.05)$. In RNA analysis no increased CEA expression was detectable.

Figure 2 depicts the course of ${ }^{131} \mathrm{I}-$ TF2 uptake in HT29 and T84 cells. After irradiation with $10 \mathrm{~Gy}$, the ${ }^{131} \mathrm{I}-\mathrm{TF} 2$ uptake increased during the first 24 hours up to $>200 \%$ when compared to sham-irradiated cells. At all time points of assessment, antibody uptake was significantly increased in both cell lines after irradiation. The enhanced uptake 
of ${ }^{131} \mathrm{I}-\mathrm{TF} 2$ could be blocked by preincubation with 50 -fold "cold" TF2. At least, a higher ${ }^{131}$ I-TF2 uptake was significantly associated with the irradiation dosage in both cell lines.

The enhanced uptake of the pretargeting system was only partially associated with a higher percentage of CEA expression at the RNA level. In T84 cells, there were slightly elevated CEA expression levels detectable after irradiation with 10 Gy (Table 2).

\section{Apoptosis}

Only SW480 cells showed a significant increase in apoptosis $(\mathrm{p}<0.05)$ occurring 48 hours after irradiation with 4 Gy (Figure 3). Compared to sham-irradiated cancer cells, there was no elevated apoptosis in HT29 and T84 cells after irradiation.

\section{Discussion}

In this study, we demonstrated a novel ${ }^{131}$ I-TF2-111 In-IMP-288 pretargeting system for semiquantitative evaluation of tumor cell viability after irradiation. In untreated cells, there was a linear correlation between individual tumor cell count and uptake detectable. In this simple and one-dimensional ${ }^{131}$ I-TF2${ }^{111}$ In-IMP-288 pretargeting system model, therapy-induced changes of CEA expression or binding affinity may not be considered.

Irradiation increased the specific uptake of the pretargeting system compared to shame-irradiated cells within the first few days in a dose dependent manner, up to 4-fold after a single dose of $10 \mathrm{~Gy}$ and 72 hours. Considering the mechanisms for this increase, we can exclude the contribution of CEA from nonviable cells by trypan blue exclusion. In addition, CEA from cell debris was removed by several washing steps in our protocol. An increased influx of the radiopharmaceutical into the cells after irradiation should be associated with an elevated rate of apoptotic cells. However, only in one cell line (Figure 3) was an increased rate of apoptosis detected after irradiation. A further factor might be an increased expression of CEA on the cell surface, based on an increased de novo synthesis or translocation of CEA. Our RNA analyses demonstrated a primarily posttranscriptional increase of CEA. The reasons for the increased expression of several targets for tumor imaging after irradiation are still unknown. However, it was demonstrated previously that the uptake of several pharmaceuticals was increased early after therapy $[25,30,31]$. Our findings are consistent with data describing an enhanced uptake of different radiopharmaceuticals induced by irradiation of different solid tumors [7, 12, 26, 44].

Patients in our planned clinical trial will be treated according to the CAO/AIO/ARO-04 protocol [21, 39]. Immuno-PET/CT will be performed pretherapeutically (PET/CT1) within the third week of RCT (PET/CT2) and immediately prior to resection of the rectal specimen (PET/CT3). In vitro experiments could not be projected directly to in vivo investigations. However, we suggest that CEA-mediated uptake on
PET/CT within the third week of therapy should not be dominated by an early increase of the uptake of the pretargeting system. CEA is a glycoprotein made by the cell and expressed on the cell surface. It will be released by damaged cells into the environment and will be absorbed quickly. Any decrease at this point in time should be a clear indication of tumor response. In addition metabolic downsizing of the primary tumor and metastatic spread should be quantitatively recorded within this approach.

\section{Conclusions}

Our in vitro testing showed that the novel ${ }^{131}$ I-TF2-111 InIMP-288 pretargeting system specifically binds to CEA-expressing colorectal cancer cells without cytotoxic side effects. The uptake of the radioimmunoconjugate can be used for semiquantitative evaluation of tumor cell viability, especially after neoadjuvant radiochemotherapy.

\section{Acknowledgments}

This work was supported by the German Research Foundation (DFG) as a part of the clinical research group 179 (KFO179: Biological basis of individual tumor response in patients with rectal cancer). The authors thank Ms. Christa Angerstein for her technical support, and Drs. D.M. Goldenberg, Chien-Hsing Chang, William McBride, and Edmund A Rossi (Immunomedics, Inc., and IBC Pharmaceuticals, Inc., USA) for providing the antibody and peptide.

\section{References}

1. Barbaro B, Fiorucci C, Tebala C, et al. Locally advanced rectal cancer: MR imaging in prediction of response after preoperative chemotherapy and radiation therapy. Radiology 2009;250:730-9.

2. Calcagno AM, Chewning KJ, Wu CP, et al. Plasma membrane calcium ATPase (PMCA4): a housekeeper for RT-PCR relative quantification of polytopic membrane proteins. BMC Mol Biol 2006;7:29.

3. Calvo FA, Domper M, Matute R, et al. 18F-FDG positron emission tomography staging and restaging in rectal cancer treated with preoperative chemoradiation. Int J Radiat Oncol Biol Phys 2004;58:528-35.

4. Chen CC, Lee RC, Lin JK, et al. How accurate is magnetic resonance imaging in restaging rectal cancer in patients receiving preoperative combined chemoradiotherapy? Dis Colon Rectum 2005;48:722-8.

5. Cicinnati VR, Shen $Q$, Sotiropoulos GC, et al. Validation of putative reference genes for gene expression studies in human hepatocellular carcinoma using real-time quantitative RT-PCR. BMC Cancer 2008;8:350.

6. Fantini J, Rognoni JB, Culouscou JM, et al. Induction of polarized apical expression and vectorial release of carcinoembryonic antigen (CEA) during the process of differentiation of HT29-D4 cells. J Cell Physiol 1989;141:126-34.

7. Furuta M, Hasegawa M, Hayakawa K, et al. Rapid rise in FDG uptake in an irradiated human tumour xenograft. Eur J Nucl Med 1997;24:435-8.

8. Goldenberg DM, Chatal JF, Barbet J, et al. Cancer Imaging and Therapy with Bispecific Antibody Pretargeting. Update Cancer Ther 2007;2:19-31.

9. Goldstein MJ, Mitchell EP. Carcinoembryonic antigen in the staging and follow-up of patients with colorectal cancer. Cancer Invest 2005;23: 338-51.

10. Guerra L, Niespolo R, Di Pisa G, et al. Change in glucose metabolism measured by $18 \mathrm{~F}-\mathrm{FDG}$ PET/CT as a predictor of histopathologic response to neoadjuvant treatment in rectal cancer. Abdom Imaging 2009 Dec 22 (Epub ahead of print); DOI: 10.1007/s00261-009-9594-8

11. Hicks RJ, Ware RE, Lau EW. PET/CT: will it change the way that we use CT in cancer imaging? Cancer Imaging 2006;6:S52-62. 
12. Higashi T, Fisher SJ, Brown RS, et al. Evaluation of the early effect of local irradiation on normal rodent bone marrow metabolism using FDG: preclinical PET studies. J Nucl Med 2000;41:2026-35.

13. Hoffer PB, Lathrop K, Bekerman C, et al. Use of 131-I-CEA antibody as a tumor scanning agent. J Nucl Med 1974;15:323-7.

14. Janssen MH OM, van Stiphout RG, Buijsen J, et al. Evaluation of early metabolic responses in rectal cancer during combined radiochemotherapy or radiotherapy alone: sequential FDG-PET-CT findings. Radiother Oncol 2010;94:151-55.

15. Karacay H, Sharkey RM, Gold DV, et al. Pretargeted radioimmunotherapy of pancreatic cancer xenografts: TF10-90Y-IMP-288 alone and combined with gemcitabine. J Nucl Med 2009;50:2008-16.

16. Lahaye MJ, Engelen SM, Kessels AG, et al. USPIO-enhanced MR imaging for nodal staging in patients with primary rectal cancer: predictive criteria. Radiology 2008;246:804-11.

17. Larbouret C, Robert B, Linard C, et al. Radiocurability by targeting tumor necrosis factor-alpha using a bispecific antibody in carcinoembryonic antigen transgenic mice. Int J Radiat Oncol Biol Phys 2007;69:1231-7.

18. Liersch T, Langer $C$, Jakob $C$, et al. [Preoperative diagnostic procedures in locally advanced rectal carcinoma ( $>$ or $=\mathrm{T} 3$ or $\mathrm{N}+$ ). What does endoluminal ultrasound achieve at staging and restaging (after neoadjuvant radiochemotherapy) in contrast to computed tomography?]. Chirurg 2003;74:224-34.

19. Liersch T, Meller J, Bittrich M, et al. Update of carcinoembryonic antigen radioimmunotherapy with (131)I-labetuzumab after salvage resection of colorectal liver metastases: comparison of outcome to a contemporaneous control group. Ann Surg Oncol 2007;14:2577-90.

20. Liersch T, Meller J, Kulle B, et al. Phase II trial of carcinoembryonic antigen radioimmunotherapy with 131I-labetuzumab after salvage resection of colorectal metastases in the liver: five-year safety and efficacy results. J Clin Oncol 2005;23:6763-70.

21. Liersch $\mathrm{T}$, Rothe $\mathrm{H}$, Ghadimi BM, et al. [Individualizing treatment for locally advanced rectal cancer]. Chirurg 2009;80:281-93.

22. Marquardt F, Rödel F, Capalbo G, et al. Molecular targeted treatment and radiation therapy for rectal cancer. Strahlenther Onkol 2009;185:371-8.

23. MERCURY Study Group. Extramural depth of tumor invasion at thin-section MR in patients with rectal cancer: results of the MERCURY study. Radiology 2007;243:132-9

24. McBride WJ, Zanzonico P, Sharkey RM, et al. Bispecific antibody pretargeting PET (immunoPET) with an 124I-labeled hapten-peptide. J Nucl Med 2006;47:1678-88.

25. Meller $B$, Deisting $W$, Wenzel $B E$, et al. Increased radioiodine uptake of thyroid cell cultures after external irradiation. Strahlenther Onkol 2006;182:30-6.

26. Ohira H, Kubota K, Ohuchi N, et al. Comparison of intratumoral distribution of $99 \mathrm{mTc}-\mathrm{MIBI}$ and deoxyglucose in mouse breast cancer models. $\mathrm{J} \mathrm{Nucl}$ Med 2000;41:1561-8.

27. Park JW, Lim SB, Kim DY, et al. Carcinoembryonic antigen as a predictor of pathologic response and a prognostic factor in locally advanced rectal cancer patients treated with preoperative chemoradiotherapy and surgery. Int J Radiat Oncol Biol Phys 2009;74:810-7.

28. Paskeviciute B, Bolling T, Brinkmann M, et al. Impact of (18)F-FDG-PET/CT on staging and irradiation of patients with locally advanced rectal cancer. Strahlenther Onkol 2009;185:260-5.

29. Pelosi E, Deandreis D. The role of 18F-fluoro-deoxy-glucose positron emission tomography (FDG-PET) in the management of patients with colorectal cancer. Eur J Surg Oncol 2007;33:1-6.

30. Rades D, Wolff C, Nadrowitz R, et al. Radioactive EGFR antibody cetuximab in multimodal cancer treatment: stability and synergistic effects with radiotherapy. Int J Radiat Oncol Biol Phys 2009;75:1226-31.
31. Riemann B, Konemann S, Popping D, et al. Early effects of irradiation on [(123)I]-IMT and [(18)F]-FDG uptake in rat C6 glioma cells. Strahlenther Onkol 2004;180:434-41.

32. Rödel C, Arnold D, Hipp M, et al. Phase I-II trial of cetuximab, capecitabine, oxaliplatin, and radiotherapy as preoperative treatment in rectal cancer. Int J Radiat Oncol Biol Phys 2008;70:1081-6.

33. Rödel C, Grabenbauer GG, Papadopoulos T, et al. Phase I/II trial of capecitabine, oxaliplatin, and radiation for rectal cancer. J Clin Oncol 2003;21:3098-104.

34. Rödel C, Liersch T, Hermann RM, et al. Multicenter phase II trial of chemoradiation with oxaliplatin for rectal cancer. J Clin Oncol 2007;25:110-7.

35. Rödel C, Martus P, Papadoupolos T, et al. Prognostic significance of tumor regression after preoperative chemoradiotherapy for rectal cancer. $\mathrm{J}$ Clin Oncol 2005;23:8688-96.

36. Rödel C, Sauer R, Fietkau R. [The role of magnetic resonance imaging to select patients for preoperative treatment in rectal cancer]. Strahlenther Onkol 2009;185:488-92.

37. Rossi EA, Goldenberg DM, Cardillo TM, et al. Stably tethered multifunctional structures of defined composition made by the dock and lock method for use in cancer targeting. Proc Natl Acad Sci U S A 2006;103:6841-6.

38. Sauer R, Becker H, Hohenberger W, et al. Preoperative versus postoperative chemoradiotherapy for rectal cancer. N Engl J Med 2004;351:1731-40.

39. Sauer R, Fietkau R, Wittekind C, et al. Adjuvant versus neoadjuvant radiochemotherapy for locally advanced rectal cancer. A progress report of a phase-III randomized trial (protocol CA0/ARO/AI0-94). Strahlenther 0nkol 2001;177:173-81.

40. Sharkey RM, McBride WJ, Karacay $H$, et al. A universal pretargeting system for cancer detection and therapy using bispecific antibody. Cancer Res 2003;63:354-63.

41. Tan E, Gouvas N, Nicholls RJ, et al. Diagnostic precision of carcinoembryonic antigen in the detection of recurrence of colorectal cancer. Surg Oncol 2009;18:15-24.

42. Weiss C, Arnold D, Dellas K, et al. Preoperative radiotherapy of advanced rectal cancer with capecitabine and oxaliplatin with or without cetuximab: a pooled analysis of three prospective phase I-II trials. Int J Radiat Oncol Biol Phys 2010;78:472-8.

43. Wolff HA, Gaedcke J, Jung K, et al. High-grade acute organ toxicity during preoperative radiochemotherapy as positive predictor for complete histopathologic tumor regression in multimodal treatment of locally advanced rectal cancer. Strahlenther Onkol 2010;186:30-5.

44. Yamamoto T, Nishizawa S, Maruyama I, et al. Acute effects of stereotactic radiosurgery on the kinetics of glucose metabolism in metastatic brain tumors: FDG PET study. Ann Nucl Med 2001;15:103-9.

45. Yoon SM, Kim DY, Kim TH, et al. Clinical parameters predicting pathologic tumor response after preoperative chemoradiotherapy for rectal cancer. Int J Radiat Oncol Biol Phys 2007;69:1167-72.

\author{
Address for Correspondence \\ PD Dr. Birgit Meller \\ Department of Nuclear Medicine \\ University Medical Center \\ Georg-August-University Göttingen \\ Robert-Koch-Str. 40 \\ 37538 Göttingen \\ Germany \\ Phone (+49/551) 39-4984, Fax -8526 \\ e-mail:meller.birgit@googlemail.com
}

